\title{
Calcium Imaging Reveals Nicotinic Acetylcholine Receptors on Cultured Mushroom Body Neurons
}

\author{
GERD BICKER AND SABINE KREISSL \\ Institut für Neurobiologie der Freien Universität Berlin, D-14195 Berlin, Germany
}

SUMMARY AND CONCLUSIONS

$l$. We used fluorescence imaging with the visible wavelength indicator fluo-3 to investigate the calcium responses to cholinergic ligands of honeybee Kenyon cells in primary culture.

2. Application of acetylcholine $(\mathrm{ACh})$ or nicotine, but not pilocarpine, promoted a calcium influx into the cell body and neurites. The increase in intracellular calcium after $\mathrm{ACh}$ stimulation was blocked by $\alpha$-bungarotoxin. These results support previous histochemical studies that suggested the expression of nicotinic cholinergic receptors on Kenyon cells.

3. After depolarization with high $\mathrm{K}^{+}$solution fluorescence increased in the somata and neurites, which indicates the presence of voltage-gated $\mathrm{Ca}^{2+}$ channels in Kenyon cell membranes.

\section{INTRODUCTION}

Learning studies in Apis and Drosophila have provided converging lines of evidence that the mushroom bodies are important neuropiles for the formation of olfactory memory in the insect brain. Cooling of the mushroom bodies of honeybees interfered with memory consolidation (Erber et al. 1980; Menzel et al. 1974). Drosophila mutants with structural defects in the mushroom body architecture were deficient in olfactory conditioning but not in sensory discrimination of the odorants (Heisenberg et al. 1985). Recent molecular genetic studies have demonstrated that the gene products of two olfactory learning mutants, dunce and rutabaga, are preferentially expressed in the mushroom bodies (Han et al. 1992; Nighorn et al. 1991).

The characteristic shape and anatomic structure of this neuropile is largely determined by the parallel projecting Kenyon cells, intrinsic to the mushroom body. A mushroom body in the brain of the bee contains $\sim 170,000$ Kenyon cells, which receive among other sensory modalities, olfactory input via the relay neurons of the antennoglomerural tracts (Mobbs 1982). Histochemical staining for acetylcholinesterase $(\mathrm{AChE})$ indicated cholinergic transmission into the mushroom body via a subset of antennoglomerular tract fibers (Kreissl and Bicker 1989). An antiserum generated against locust nicotinic receptors (Breer et al. 1985) stained somata and processes of Kenyon cells (Kreissl and Bicker 1989). Furthermore, quantitative autoradiography localized $\alpha$-bungarotoxin binding sites in the mushroom body neuropile (Scheidler et al. 1990). However, despite the many anatomic studies and the recent interest in the molecular bases of olfactory learning in insects, there is no information available about the physiological responses of Kenyon cells to application of transmitters of afferent pathways.
We have developed an in vitro approach to characterize the cellular properties of Kenyon cells (Kreissl and Bicker 1992). It is possible to remove the complete mushroom body neuropile including its adhering Kenyon cell somata by means of microdissection from the brains of pupal honeybees. After dissociation and plating, the cell bodies readily sprouted new process in cell culture. In this study, we used video microscopy with the calcium indicator dye fluo-3 to investigate the calcium responses of Kenyon cells to application of cholinergic ligands.

\section{METHODS}

\section{Cell culture}

Three to five days before adult eclosion, brains of honeybee pupae were dissected out of the head capsule in cold culture medium. Details of the dissection of mushroom bodies and the establishment of primary cell cultures have been described elsewhere (Kreissl and Bicker 1992). After dissociation, cells were cultured for a week to allow for neurite outgrowth. The dissociated cell cultures contained a pure population of Kenyon cells and a few easily distinguishable phase-dark glial cells.

\section{Calcium imaging}

Changes in cytosolic calcium concentration were estimated using the fluorescent membrane-permanent probe fluo-3-AM (Molecular Probes) (Tsien 1989). Cells were loaded in $5 \mu \mathrm{M}$ fluo-3AM with the addition of $0.025 \%$ Synperonic PE/F127 (Boehringer) for $45 \mathrm{~min}$ at room temperature, washed with medium, and placed on the stage of a Zeiss Axiovert 35 microscope. A gravity-fed perfusion system allowed the continuous perfusion of cells with Ringer solution at a flow rate of $10 \mathrm{ml} / \mathrm{min}$ and the sequential application of a volume of $100 \mu \mathrm{l}$ of transmitters and drugs. Rapid solution exchange in the perfusion system was facilitated by maintaining a low chamber fluid volume of $800 \mu \mathrm{l}$. Normal Ringer solution is composed of the following (in $\mathrm{mM}$ ): 135 $\mathrm{NaCl}, 5 \mathrm{KCl}, 10 \mathrm{MgCl}_{2}, 1.6 \mathrm{CaCl}_{2}, 50$ sucrose, 65 tris(hydroxymethyl)aminomethane (tris)- $\mathrm{HCl}$ buffer; $\mathrm{pH}$ 7.2. All chemicals were obtained from Sigma. A $1 \%$ neutral density filter was used to attenuate the excitation light emitted by the mercury lamp of the microscope. The fluorescence was imaged using a Hamamatsu 2400 SIT camera interfaced with an Argus 10 image processor system and a Mitsubishi HS-M55 video recorder. Data are expressed as a change in fluorescence over baseline fluorescence percentage $\left(F-F_{0}\right) / F_{0}$ for each cell, where $F$ refers to the peak fluorescence from a cell body and $F_{0}$ represents the fluorescence of the cell body presumably at rest. If the peak fluorescence of the soma saturated the dynamic range of the camera, a region of less intense baseline fluorescence adjacent to the soma was evaluated. Usually two cells of 5-10 cells in the field of view of the microscope optics were close enough to be simultaneously captured and analyzed by the video image processing system. Fluorescence re- 

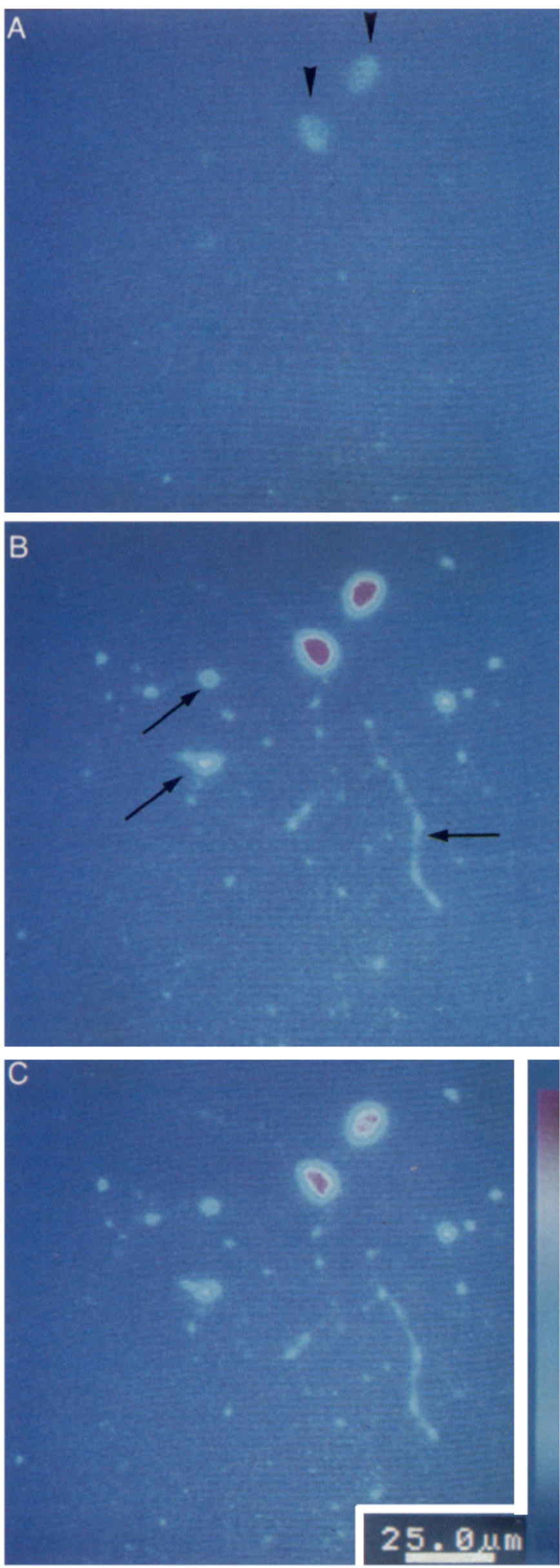

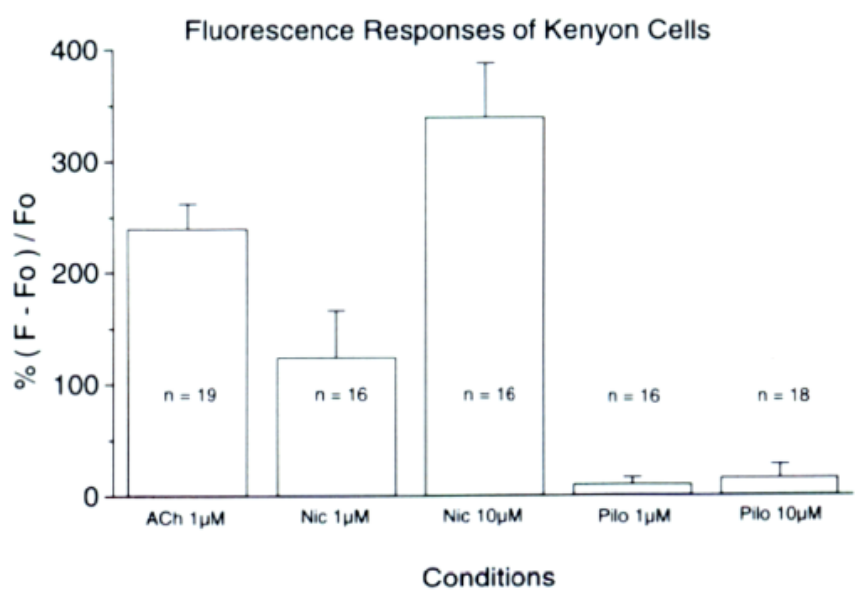

FIG. 2. Fluorescence responses of Kenyon cells. The peak fluorescence values of cell bodies reaching a maximum within a time window of $1-5 \mathrm{~s}$ after drug application are quantified. $\mathrm{ACh}$, acetylcholine; Nic, nicotine; Pilo, pilocarpine. The fluorescence response measured at the lowest concentration $(1 \mu \mathrm{M})$ of nicotine is significantly different from the fluorescence at the highest concentration $(10 \mu \mathrm{M})$ of pilocarpine $(P<0.05$; Mann-Whitney test, two tailed). Means \pm SE of $n$ cells, measured in $8-10$ cultures.

sponses that did not return to baseline after cessation of drug application, were discarded from data analysis. This occured in $6 \%$ of all measurements, mainly when cells were treated with 50 $\mathrm{mM} \mathrm{KCl}$.

\section{RESULTS}

After loading with the indicator dye, cells were challenged with pulses of $\mathrm{ACh}$. At concentrations of $100 \mathrm{nM}-$ $1 \mu \mathrm{M}$, the transmitter induced a readily detectable increase in fluorescence. As shown in Fig. 1, the fluorescence was elevated over the neurites and cell bodies. The peak fluorescence change could be most reliably evaluated over the cell bodies. An average net increase in fluorescence of $\sim 200-$ $300 \%$ over resting level was observed during the first $1-5 \mathrm{~s}$ after transmitter application, with the fluorescence decaying back to resting levels within $1 \mathrm{~min}$. Changes in the averaged peak fluorescence for transmitter and drug application are shown in Figs. 2 and 3. Nicotine caused a concentration dependend increase in fluorescence at $1-10 \mu \mathrm{M}$, whereas the muscarinic agonist pilocarpine did not show an increase in fluorescence at 1 and $10 \mu \mathrm{M}$, indicating that muscarinic receptors were unlikely to be involved in the response (Fig. 2 ). Replacing extracellular $\mathrm{Ca}^{2+}$ with $1.6 \mathrm{mM} \mathrm{Co}^{2+}$ prevented the ACh-induced increase (Fig. 3), demonstrating that extracellular $\mathrm{Ca}^{2+}$ was required. Preincubating the cultures for $30 \mathrm{~min}$ with $100 \mathrm{nM} \alpha$-bungarotoxin prevented $\mathrm{ACh}$ from raising the fluorescence over baseline levels (Fig. 3).

Depolarizing the neurons by application of high $\mathrm{K}^{+}(50$ $\mathrm{mM}$ ) caused a large increase in fluorescence (Fig. 3). Fluorescence signals of somata and neurites returned only after

FIG. 1. Fluorescence imaging with the calcium indicator fluo-3 in cultured Kenyon cells. Fluorescence images of 2 Kenyon cells before $(a), 2 \mathrm{~s}$ after $(b)$, and $30 \mathrm{~s}$ after $(c)$ bath application of $1 \mu \mathrm{M} \mathrm{ACh}$. The camera was set at high gain to visualize the thin processes $(\rightarrow)$. Fluorescence increase in the 2 cell bodies $(\downarrow)$ did saturate the dynamic range of the camera. Arbitrary pseudocolor values for free cytosolic $\mathrm{Ca}^{2+}$ are indicated. 


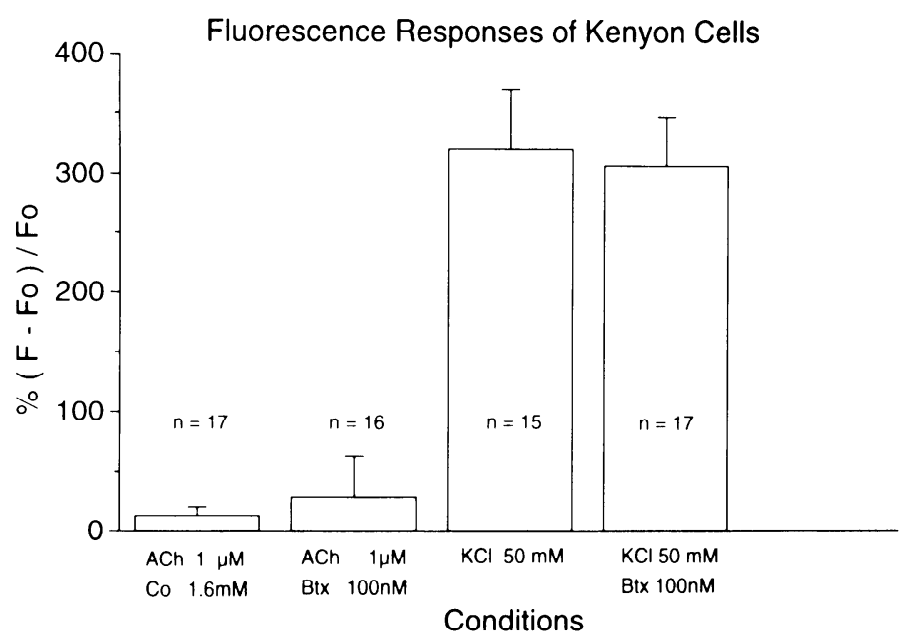

FIG. 3. Fluorescence responses of Kenyon cells. The peak fluorescence values of cell bodies reaching a maximum within a time window of $1-5 \mathrm{~s}$ after drug application are quantified. $\mathrm{ACh}+\mathrm{Co}$, extracellular $\mathrm{CaCl}_{2}$ was replaced by $1.6 \mathrm{mM} \mathrm{CoCl} 210 \mathrm{~min}$ before $\mathrm{ACh}$ application; $\mathrm{ACh}+\mathrm{Btx}$, $100 \mathrm{nM}$ ( $\gamma$-bungarotoxin were present $30 \mathrm{~min}$ before $\mathrm{ACh}$ application; $\mathrm{KCl}, \mathrm{KCl}$ concentration in Ringer solution was increased to $50 \mathrm{mM}$ and sucrose reduced. Mcans $\pm \mathrm{SE}$ of $n$ cells, measured in $8-10$ cultures.

3 min to baseline levels. Because $\alpha$-bungarotoxin did not prevent the $\mathrm{K}^{+}$-induced fluorescence, its blockade seems to be specific to nicotinic $\mathrm{ACh}$ receptors.

\section{DISCUSSION}

Because of their thin processes and small diameter cell bodies, ranging in bees from 6 to $10 \mu \mathrm{m}$, the Kenyon cells of the insect brain have resisted physiological investigations for a long time. However, the development of a primary cell culture system for defined areas of the honeybee brain (Kreissl and Bicker 1992) has enabled ready access to individual Kenyon cells for the application of transmitters combined with microfluorimetric measurements of $\mathrm{Ca}^{2+}$ signals. The results show an intracellular $\mathrm{Ca}^{2+}$ increase after stimulation with $\mathrm{ACh}$ and nicotine. The specific block of the cholinergic response by $\alpha$-bungarotoxin provides physiological evidence that Kenyon cells express nicotinic ACh receptors. Stimulation with the muscarinic agonist pilocarpine did not increase the fluorescence, suggesting that under the current stimulus protocol muscarinic receptors were unlikely to be involved in the response. A rise in fluorescence after depolarization with high $\mathrm{K}^{+}$solution indicates the presence of voltage-gated $\mathrm{Ca}^{2+}$ channels in Kenyon cell membranes. Presumably, binding of ACh to nicotinic receptors triggers a conductance increase to cations and the resulting depolarization of the membrane caused influx of extracellular $\mathrm{Ca}^{2+}$ through voltage-activated $\mathrm{Ca}^{2+}$ channels. No attempts have been made to distinguish the various contributions to the fluorescence increase by $\mathrm{Ca}^{2+}$ flux by 1) the transmembrane channel of the $\mathrm{ACh}$ receptor, 2 ) voltage-dependent $\mathrm{Ca}^{2+}$ channels, and 3 ) the possibility of a $\mathrm{Ca}^{2+}$-induced $\mathrm{Ca}^{2+}$ release from internal stores ( Tsien and Tsien 1990). The calcium imaging experiments support our previous immunocytochemical studies (Kreissl and Bicker 1989) suggesting the expression of nicotinic cholinergic receptors on Kenyon cells.

Calcium is a key regulatory messenger in a wide variety of cellular mechanisms and of neuronal plasticity in particular. The microfluorometric studies on cultured Kenyon cells might also prove useful for identifying essential cellular responses to aminergic transmitters that influence storage and retrieval processes of olfactory memory in the brain of the bee (Bicker and Menzel 1989).

\section{REFERENCES}

BICKER, G. AND MENZEL, R. Chemical codes for the control of behaviour in arthropods. Nature Lond. 337: 33-39, 1989.

BREER, H., KLEENE, R., AND HINZ, G. Molecular forms and subunit structure of the acetylcholine receptor in the central nervous system of insects. J. Neurosci. 5: 3386-3392, 1985.

ERber, J., Masuhr, T., AND MENZEL, R. Localization of short-term memory in the brain of the bee Apis mellifera. Physiol. Entomol. 5: 343-358, 1980

IIan, P. L., Levin L. R., Reed R.R., And Davis R. L. Preferential expression of the Drosophilia rutabaga gene in mushroom bodies, neural centers for learning in insects. Neuron 9: 619-627, 1992.

Heisenberg, M., Borst, A., Wagner, S., and Byers, D. Drosophila mushroom body mutants are deficient in olfactory learning. J. Neurogenet. 2: 1-30, 1985 .

KREISSL, S. AND BICKER, G. Histochemistry of acetylcholinesterase and immunocytochemistry of an acetylcholine receptor-like antigen in the brain of the honeybee. J. Comp. Neurol. 286: 71-84, 1989.

KREISSL, S. AND BICKER, G. Dissociated neurons of the pupal honeybee brain in cell culture. J. Neurocytol. 21: 545-556, 1992.

MenZel, R., ERBER, J., AND MASUhr, T. Learning and memory in the honey bee. In: Experimental Analysis of Insect Behavior, edited by L. Barton Browne. Berlin: Springer-Verlag, 1974, p. 195-218.

MobBS, P. G. The brain of the honeybee Apis mellifera. I. The connections and spatial organization of the mushroom bodies. Phil. Trans. R. Soc. Lond. B Biol. Sci. 298: 309-354, 1982.

Nighorn, A., Healy, M. J.. AND Davis, R. L. The cyclic AMP phosphodicsterase encoded by the Drosophila dunce gene is concentrated in the mushroom body neuropil. Neuron 6: 455-467, 1991.

Scheidler, A., Kaulen, P., Brüning, G., and Erber J. Quantitative autoradiographic localization of $\left[{ }^{125} \mathrm{I}\right] \alpha$-bungarotoxin binding sites in the honeybee brain. Brain Res. 534: 332-335, 1990.

TSIEN, R. W. AND TsIEN, R. Y. Calcium channels, stores, and oscillations. Annu. Rev. Cell. Biol. 6: 715-760, 1990.

TSIEN, R. Y. Fluorescent probes of cell signalling. Annu. Rev. Neurosci. 12: 13-31, 1989. 